\title{
PRINCIPLES OF OPTIMAL SAMPLING FOR CHARACTERIZATION OF SOLID RADIOACTIVE WASTE OF THE IGNALINA NUCLEAR POWER PLANT
}

\author{
E. Maceika, V. Remeikis, L. Juodis, A. Gudelis, A. Plukis, R. Plukienė, G. Duškesas, \\ and D. Baltrūnas \\ Institute of Physics, Savanoriu 231, LT-02300 Vilnius, Lithuania \\ E-mail: emaceika@ar.fi.lt
}

Received 31 July 2009; revised 9 September 2009; accepted 15 September 2009

\begin{abstract}
Operation of the Ignalina Nuclear Power Plant (INPP) resulted in about 7500 tons of solid radioactive waste kept in 45 sections of four storage facilities (No 155, 155/1, 157, 157/1) at the INPP site. For safe and efficient decommissioning of these storages it is important to know the waste inventory. The nuclide vector $(\mathrm{NV})$ method was used for characterization of the radionuclide inventory in the storages of solid radioactive waste (SRW). A well planned sampling and radionuclide composition measurements were needed to evaluate scaling factors of the NV.

The optimal number of the samples $N$, to be taken from every storage section of SRW, was evaluated by using a wellknown relationship between error of the mean $\Delta$ and dispersion $\sigma: \Delta=\sigma / \sqrt{N}$. The specific activity ratio (scaling factor) of ${ }^{137} \mathrm{Cs}$ to ${ }^{60} \mathrm{Co}$ radionuclides in the radioactive waste was selected as the most informative ratio, reflecting dispersion of the nuclide vector. Computer modelling of the radioactive waste streams and Monte Carlo simulations of the most representative ${ }^{137} \mathrm{Cs} /{ }^{60} \mathrm{Co}$ activity ratio dispersion in each waste storage section were done based on the historical data about the SRW management at the INPP and spectrometric measurements of the radionuclide activity of SRW at the main waste collection points. The evaluated optimal average number of required samples from the SRW storage sections was 7, whereas the number of required samples varied from 4 (storage facility No 157/1, section 1) to 19 (storage facility No 157/1, sections No 9 and 19/2). Keywords: Ignalina Nuclear Power Plant, RBMK-1500, solid radioactive waste, nuclide vector, waste characterization, sampling, Monte Carlo modelling
\end{abstract}

PACS: $28.41 . \mathrm{Kw}, 07.05 . \mathrm{Tp}$.

\section{Introduction}

Operation of nuclear power plants results in accumulation of the radioactive waste. Large volume of solid and liquid radioactive waste has been collected in the storage facilities of the Ignalina Nuclear Power Plant (INPP) during the years of its operation. However, these facilities are not suitable for waste disposal due to non-compliance of collected radioactive waste with the current requirements for radioactive waste management and disposal practice [1-3]. The principal issue is the information about the radionuclide composition of radioactive waste. Critical radionuclides and their activities in the waste have to be determined. However, the quantity of some high energy emitters, such as ${ }^{60} \mathrm{Co}$ and ${ }^{137} \mathrm{Cs}$, can be determined relatively simply by a direct spectrometric measurement of the radioactive waste package. The majority of other radionuclides are either weak $\gamma$ or short-range $\beta$ and $\alpha$ emitters, therefore they are difficult-to-measure by simple non-destructive techniques. Activity of other radiologically very important radionuclides (e.g. ${ }^{129} \mathrm{I}$ ) can be evaluated by indirect methods $[4,5]$. This problem can be solved by application of the nuclide vector (NV) method [6] as well. The method is based on correlations between the activities of radionuclides present in waste. This is due to the fact that the activity ratio is predetermined by the radionuclide generation process in nuclear fuel and activation in reactor constructions, as well as by the radioactive waste generation during the other routine processes at the nuclear power plant [7]. Depending on the origin of waste either ${ }^{60} \mathrm{Co}$ or ${ }^{137} \mathrm{Cs}$ can be selected as a "key nuclide", whose activity is correlated with the activity of difficult-to-measure radionuclides by some theoretically or experimentally determined ratio, the socalled scaling factor. The determination of scaling factors is the main problem enabling the application of the nuclide vector method. However, the determina- 
tion of these data causes many difficulties due to big variation of measured activities in radioactive waste. This is mainly due to the fact that complex radionuclide generation and migration processes are involved in the radioactive waste generation scheme [8]. Therefore, in order to assure the reliability of scaling factors the necessary amount of waste samples to be taken and measured needs to be evaluated. The laboratory measurement of radionuclide activities is rather costly and time-consuming, therefore the optimal amount of measurements for the nuclide vector determination should be found. The aim of this work is to provide the insight into the principles of development of the optimal sampling program of the INPP radioactive waste.

\section{Historical data}

During more than 25 years of operation of the INPP (the first RBMK-1500 Unit was in operation from 1983, the second one from 1987) more than 7500 tons of solid radioactive waste (SRW) were collected in the special storage facilities [9]. The waste is stored in four facilities which are divided into separate sections. The waste was loaded into the sections according to classification criteria: the dose rate and flammability. The waste is segregated into three groups according to the dose rate at a distance of $10 \mathrm{~cm}$ from surface: the 1st group, low activity $\left(6 \cdot 10^{-4}-0.3 \mathrm{mSv} / \mathrm{h}\right)$ waste; the 2 nd group, intermediate activity $(0.3-10 \mathrm{mSv} / \mathrm{h})$ waste; and the $3 \mathrm{rd}$ group, high activity $(>10 \mathrm{mSv} / \mathrm{h})$ waste. According to the flammability criterion the waste is separated into the flammable, non-flammable, and mixed. The waste is collected in 45 sections: facility No 155, 1 section; facility No 155/1, 3 sections; facility No 157, 15 sections, and facility No 157/1, 26 sections. According to the decommissioning plan of the INPP [9] all collected waste shall be retrieved from existing storage facilities and their nuclide composition shall be determined. After radiological characterization and appropriate treatment the waste will be packaged and disposed off in the licensed disposal facilities. Therefore, the reliable determination of the nuclide composition is a key issue in the INNP decommissioning process.

Several sources of information helped to solve the problem of the waste characterization:

- historical data on operation features and data of ever performed waste radionuclide activity measurements;

- collection of new samples and performance of new well planned measurements;
- using modelling techniques of radionuclide generation in SRW due to nuclear fuel fission and activation of the reactor constructions and materials.

All operational solid radioactive waste, generated at the INPP, is collected and sorted according to the type and category and is loaded into the containers at the certain waste collection points. Afterwards containers are transported to the storage facility and waste is downloaded into the corresponding section for storage according to the category and type of the waste. Basic data about the radioactive waste origin date, place of collection, volume, mass, the dose rate, types, and category are documented in the paper passport for each SRW container. Results of the gamma spectrometric measurements of waste from some selected containers, performed twice a year from different waste collection points, are available before the year 2001. From 2001 every container with SRW was measured by a newly introduced spectrometric measuring system before downloading it into the storage section. The passports are kept in the INPP archive. Data from the paper passports are partly transferred into the INPP solid waste register electronic database (DB). It contains 10161 records covering the period from March 1984 to September 2007.

In general, completeness and reliability of available historical data on waste are low, especially spectrometric measurement data of SRW in containers before the year 2001, when a new gamma spectrometric measurement system of SRW was introduced. Data before the year 1998 provide monthly summary information on mass, volume, collection point, and seldom spectrometric measurements of SRW in containers downloaded into a certain storage section over the month. Reliability of the spectrometric data is low because measurements were performed at the side of the steel container at a distance of several metres away from the container. Therefore, data of these SRW spectrometric measurements can be treated as auxiliary only.

Since the year 1998 data for each separate container are recorded in the database. Results of the gamma spectrometric measurements are still associated with high uncertainties due to the effective shielding of container walls, variability of the SRW density and geometry, external contamination of the container walls, and other factors.

Spectrometric measurements of some $\gamma$ emitting radionuclides were done for ${ }^{60} \mathrm{Co}$ (for $93 \%$ of the containers), ${ }^{137} \mathrm{Cs}(42 \%),{ }^{54} \mathrm{Mn}(40 \%),{ }^{95} \mathrm{Nb}(31 \%),{ }^{95} \mathrm{Zr}$ $(23 \%),{ }^{134} \mathrm{Cs}(15 \%),{ }^{131} \mathrm{I}(6 \%)$, and others. 

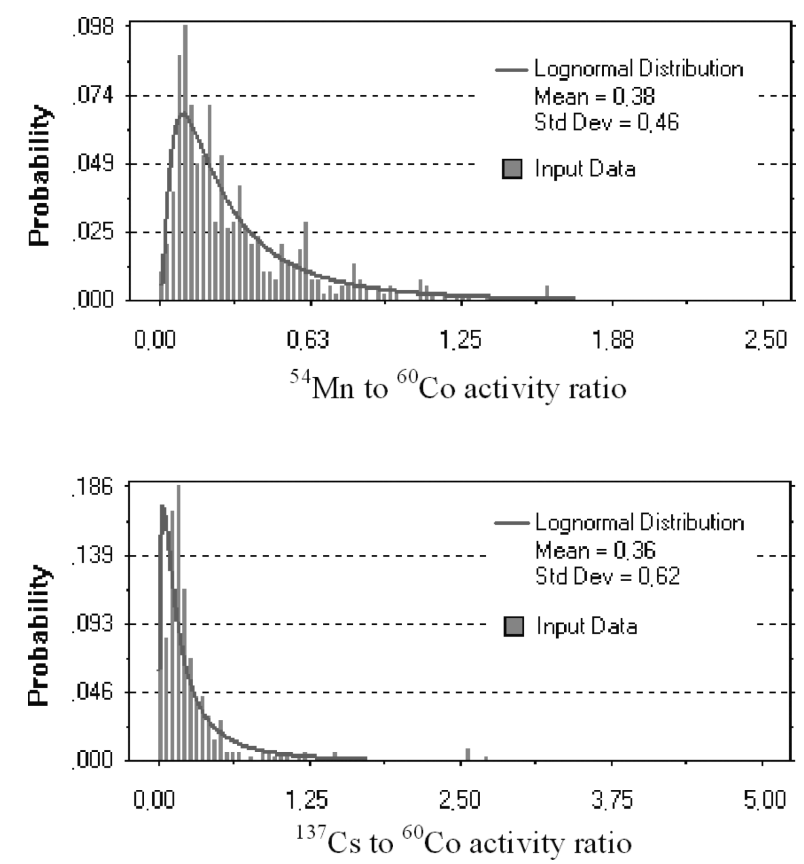

Fig. 1. Histogram of ${ }^{54} \mathrm{Mn} /{ }^{60} \mathrm{Co}$ and ${ }^{137} \mathrm{Cs} /{ }^{60} \mathrm{Co}$ activity ratios based on the historical INPP measurement data and fitted lognormal distribution (Mean and Standard Deviation) for the waste in facility No 157/1, section 20/1.

Because of the incompleteness and insufficient reliability the historical INPP spectrometric data could not be used directly for the evaluation of the SRW nuclide vector scaling factors. Therefore, new well planned sampling and measurements were needed to be done. All available historical data served as initial information for development of the optimal sampling program and the primary radioactive waste nuclide composition analysis.

\section{Mathematical approach}

The optimal number of samples (i.e. minimal sufficient number) to be taken from each section for the forthcoming evaluation of the nuclide vector scaling factors can be determined by using modelling of dispersion of radionuclide specific activity ratios. The number of samples for the evaluation of the average scaling factor with desired reliability depends on the scattering of the activity ratios from sample to sample. The larger is the scattering, the larger number of samples has to be collected. According to the central limit theorem, error $\Delta$ of the estimate of some random variable mean with $68 \%$ confidence can be calculated by the following equation [10]:

$$
\Delta=\frac{\sigma}{\sqrt{N}}
$$

where $\sigma$ is the dispersion of the distribution and $N$ is the number of samples needed. Therefore, the task turns to the identification of the radionuclide activity ratio dispersion in the waste of each storage section.

In our case the examination of the INPP database historical data showed that activity measurement ratios ${ }^{54} \mathrm{Mn} /{ }^{60} \mathrm{Co},{ }^{137} \mathrm{Cs} /{ }^{60} \mathrm{Co}$ for each section of facilities No 155, 155/1, 157, 157/1 can be conveniently approximated by the lognormal distribution law (Fig. 1).

Probability density function $f_{\eta}(x)$ of some lognormally distributed random variable $\eta$ can be expressed as follows:

$$
f_{\eta}(x)=\frac{1}{\sigma_{\ln } x \sqrt{2 \pi}} \exp \left\{-\frac{[\ln (x)-\ln (a)]^{2}}{2 \sigma_{\ln }^{2}}\right\},
$$

where the parameters of the distribution are: $a$, the geometric mean of the random variable $\eta ; \sigma_{\ln }=\ln (\mathrm{GSD})$, GSD is the geometric standard deviation of $\eta$. We are interested in the mean $\mu$ and standard deviation $\sigma$ values of lognormal distribution Eq. (1), which can be expressed as [10]

$$
\begin{aligned}
& \mu=a \cdot \exp \left(\frac{\sigma_{\ln }^{2}}{2}\right), \\
& \sigma=a^{2} \exp \left(\sigma_{\ln }^{2}\right)\left[\exp \left(\sigma_{\ln }^{2}\right)-1\right] .
\end{aligned}
$$

The necessary number of measurements to achieve a smaller error of the mean $\mu$ than $\Delta$ is evaluated in the following way:

$$
N=\left(\frac{\sigma}{\Delta}\right)^{2} .
$$

One can take the value of error $\Delta$ as some fraction of the distribution mean $\mu$, e.g., $100 \%(\Delta=\mu)$. Then the required number of samples is calculated as follows:

$$
N(100 \%)=\frac{\sigma^{2}}{\mu^{2}} .
$$

The ratio of the specific activities of ${ }^{137} \mathrm{Cs}$ to ${ }^{60} \mathrm{Co}$ radionuclides was selected as the most informative and reasonably conservative one. The mean and dispersion values of the ratio were used in Eq. (5) to estimate the required number of samples from each waste storage section of facilities No 155, 155/1, 157, 157/1 that are to be measured.

\section{Modelling}

Movement of the solid radioactive waste from the places of its origin into places of storage in the INPP was evaluated by using a solid waste mass stream model 
Table 1. Experimentally evaluated parameters of the ${ }^{137} \mathrm{Cs} /{ }^{60} \mathrm{Co}$ nuclide activity ratio lognormal distributions in solid radioactive waste, taken from the main collection points at INPP.

\begin{tabular}{|c|c|c|c|}
\hline \multirow{2}{*}{$\begin{array}{l}\text { Nuclide vector } \\
\text { scaling factor }\end{array}$} & \multirow{2}{*}{$\begin{array}{l}\text { Description } \\
\text { of the SRW collection points }\end{array}$} & \multicolumn{2}{|c|}{$\begin{array}{l}\text { Parameters of lognormal distribution of } \\
\text { the }{ }^{137} \mathrm{Cs} /{ }^{60} \mathrm{Co} \text { scaling factor values }\end{array}$} \\
\hline & & Geometric mean, $a$ & $\begin{array}{l}\text { Geometric standard } \\
\text { deviation, GSD }\end{array}$ \\
\hline NVR1 & $\begin{array}{l}\text { Chamber No } 046 \text { blocks A-1, A-2 due to operation of } \\
\text { Long parts milling devices }\end{array}$ & 0.0023 & 2.1 \\
\hline NVR2 & $\begin{array}{l}\text { Building No } 130 \text { due to repair of the Main circulation } \\
\text { circuit elements }\end{array}$ & 0.0015 & 3.3 \\
\hline NVR3 & Central reactor halls No 613 blocks A-1, A-2 & 0.11 & 2.5 \\
\hline NVR4 & $\begin{array}{l}\text { Chamber No } 625 \text { blocks A-1, A-2 due to operation } \\
\text { of the "Hot Cells" and from spent nuclear fuel disposal } \\
\text { basins hall No 632, reactor blocks A-1, A-2 }\end{array}$ & 0.13 & 3.5 \\
\hline NVR5 & Chamber D-2, corridor No 103 & 0.14 & 4.1 \\
\hline NVR6 & Chamber D-1, corridor No 103 & 0.17 & 3.8 \\
\hline NVR7 & Steam generator halls G-1 and G-2 & 0.13 & 4.3 \\
\hline NVR8 & $\begin{array}{l}\text { Chamber No } 1007 / 1,1007 / 2 \text {, and corridor } 143 \text {, } \\
\text { reactor block A-2 }\end{array}$ & 0.083 & 5.4 \\
\hline NVR9 & $\begin{array}{l}\text { Chamber No } 1007 / 1,1007 / 2,207 \text {, and corridor } 143 \text {, } \\
\text { reactor block A-1 }\end{array}$ & 0.15 & 4.6 \\
\hline NVR10 & Building No $117 / 1$ & 0.61 & 3.4 \\
\hline NVR11 & $\begin{array}{l}\text { SRW arising due to operation of SRW storage } \\
\text { Facilities No } 157 \text { and } 157 / 1\end{array}$ & 0.19 & 7.0 \\
\hline NVR12 & $\begin{array}{l}\text { INPP Operational SRW (Buildings No } 135,158 \\
151 / 154,159,156,140 / 2 \mathrm{a}, 140 / 1)\end{array}$ & 0.23 & 9.2 \\
\hline NVR13 & $\begin{array}{l}\text { Chambers No } 608 \text { with filters, } \\
\text { reactor blocks A-1, A-2 }\end{array}$ & 231.20 & 1.2 \\
\hline NVR14 & Building No 150 & 0.70 & 7.9 \\
\hline NVR15 & $\begin{array}{l}\text { Not known vector (conservative estimate of average for the waste } \\
\text { from the whole INPP) }\end{array}$ & 0.15 & 3.9 \\
\hline
\end{tabular}

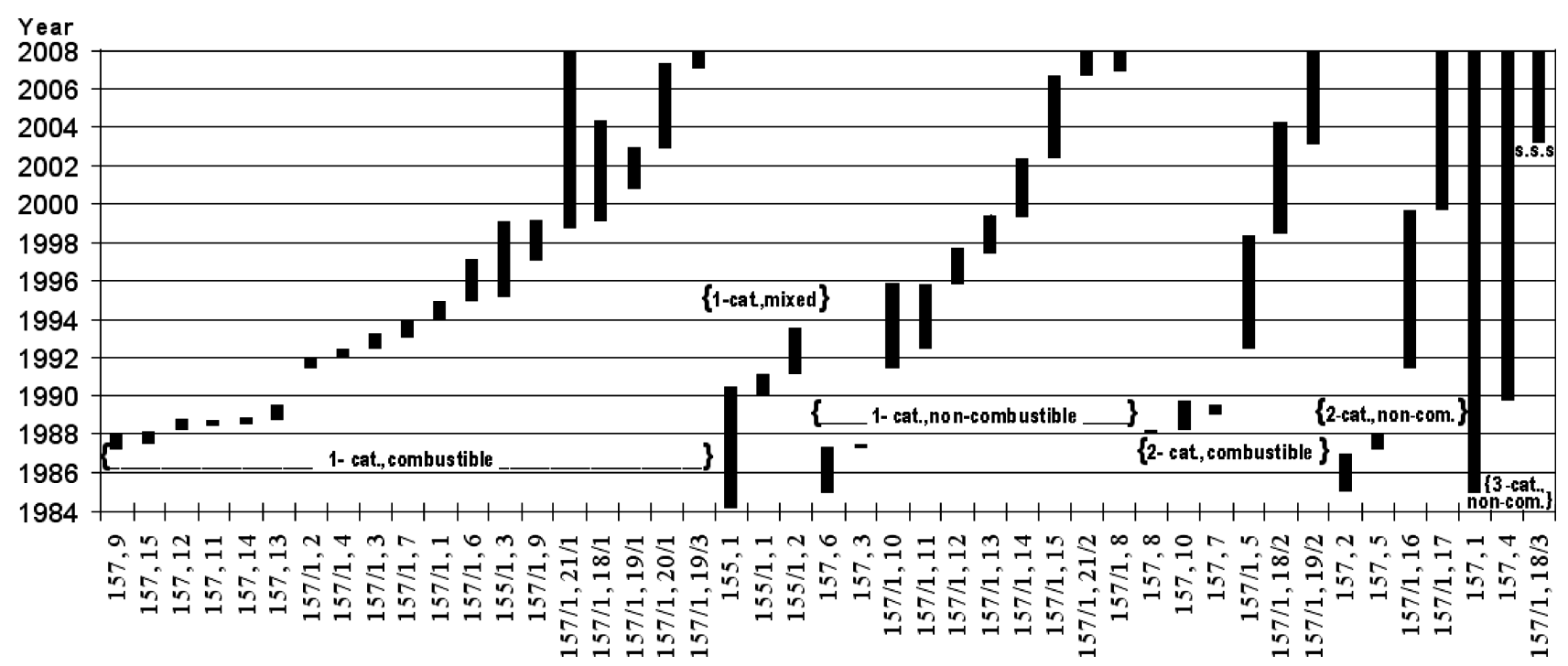

Fig. 2. Time diagram of solid waste storage facility sections filled with waste, grouped by the category (1-3) and type of the waste: combustible, non-combustible (non.com.), mixed, spent sealed sources (s.s.s).

[11]. According to the applied practice at the INPP the radioactive waste was collected in special containers at certain collection points. Different containers were used for different categories $(1,2,3)$ and types (combustible, non-combustible, mixed) of waste. Containers filled up with SRW are periodically transported to the waste storage facility and downloaded into the sections taking into account the category and type of waste. Diagram of time characteristics (beginning and end dates) of the storage sections filled with SRW is presented in Fig. 2. 


\subsection{Modelling of waste radionuclide composition in a container}

A stochastic Monte Carlo simulation of the nuclide composition distribution in the waste of each container and modelling of further collection in the corresponding section of storage were carried out in line with the waste mass stream model [11].

In the DB there is available information about the collection point and the section into which the waste was downloaded. It is reasonable to conservatively assume that dispersion of the activity ratios in a container is the same as dispersion in the waste appearing at a certain collection point during a prolonged period. The lognormal type of distribution was assumed with the empirically evaluated distribution parameters (geometric mean and geometric standard deviation), evaluated on the basis of the specially carried out sampling and spectrometric measurements of waste samples taken from the main collection points during several months [12]. At several collection points SRW was contaminated by the same source, therefore the same nuclide vector was typical of all waste coming from these collection points.

Parameters of lognormal distributions of ${ }^{137} \mathrm{Cs} /{ }^{60} \mathrm{Co}$ scaling factor values (radionuclide activity ratios), based on experimental measurements, for SRW from the INPP main collection points are presented in Table 1 .

Then the resulting distribution of the radionuclide activity ratios of SRW in the section of the storage is obtained as a mixture of distributions of the downloaded containers, weighted according to the amount of waste in each container.

If the value of the measured activity of ${ }^{137} \mathrm{Cs}$ and ${ }^{60} \mathrm{Co}$ in the waste of the container was available in the $\mathrm{DB}$, then the value of the activity ratio served as a parametric estimate of the mean of lognormal distribution for the container. If such measurement value for a container was absent, then the typical mean value of the established ratio for the waste from the collection point was assigned as a mean of lognormal distribution (see Table 1).

In both cases dispersion of the lognormal distribution was characterized by the geometric standard deviation, which was typical of a certain collection point and was evaluated from the experimental measurements (see Table 1).

All process of the formation of the mixture in the waste storage section was modelled by using Monte Carlo simulations in the environment of MS Excel with Crystall Ball ${ }^{\mathrm{TM}}$ application. A specially created macro code for each container was generating $M$ number of possible activity ratio values, distributed by the lognor-
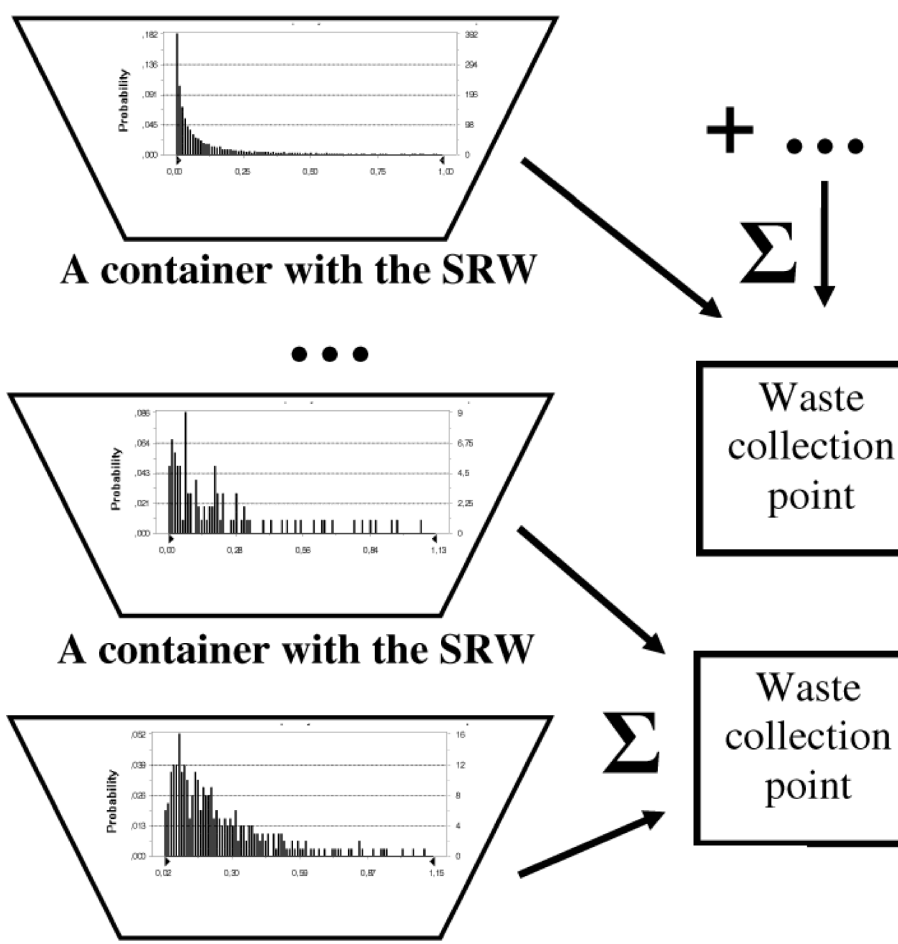

A container with the $S R W$

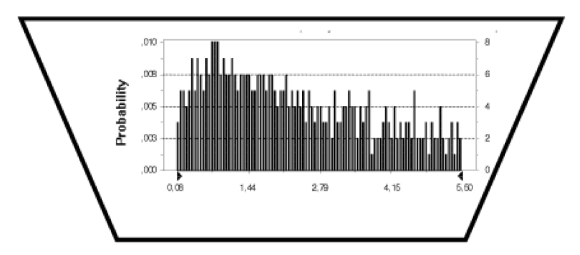

The $n^{\text {th }}$ container with the SRW

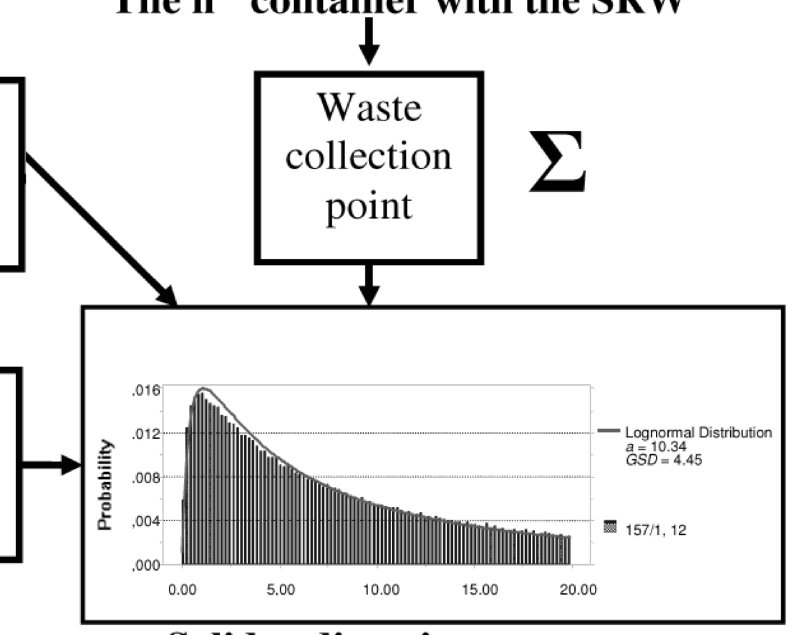

Solid radioactive waste storage section

Fig. 3. Generation of the possible set of the ${ }^{137} \mathrm{Cs}$ to ${ }^{60} \mathrm{Co}$ activity ratios for the waste in each container with the SRW and modelling of the resulting distribution of the ratio in the storage section. 
Table 2. Contributions of different nuclide vector ratios NVR1-15 in the waste of each storage section.

\begin{tabular}{|c|c|c|c|c|c|c|c|c|c|c|c|c|c|c|c|c|c|}
\hline \multirow[t]{2}{*}{$\begin{array}{c}\text { Facility } \\
\text { No }\end{array}$} & \multirow[t]{2}{*}{$\begin{array}{c}\text { Section } \\
\text { No }\end{array}$} & \multirow{2}{*}{$\begin{array}{c}\text { SRW } \\
\text { volume, } \\
\mathrm{m}^{3}\end{array}$} & \multicolumn{15}{|c|}{$\begin{array}{l}\text { Part of the corresponding nuclide vector ratio }\left(\mathrm{NVR}_{x}\right) \text { in the waste } \\
\text { of each storage section, } \%\end{array}$} \\
\hline & & & 1 & 2 & 3 & 4 & 5 & 6 & 7 & 8 & 9 & 10 & 11 & 12 & 13 & 14 & 15 \\
\hline $157 / 1$ & 16 & 1160 & 0.0 & 1.3 & 4.8 & 29.3 & 1.3 & 0.0 & 3.3 & 4.5 & 12.0 & 0.0 & 0.0 & 5.2 & 0.0 & 0.0 & 38.3 \\
\hline $157 / 1$ & 17 & 573 & 0.5 & 4.6 & 17.6 & 32.4 & 0.0 & 0.0 & 0.6 & 17.0 & 11.0 & 0.0 & 0.0 & 13.2 & 1.1 & 1.1 & 0.8 \\
\hline $157 / 1$ & $18 / 1$ & 390 & 0.0 & 1.1 & 0.0 & 0.3 & 0.0 & 20.8 & 33.6 & 5.8 & 33.2 & 0.0 & 0.0 & 4.5 & 0.0 & 0.4 & 0.3 \\
\hline $157 / 1$ & $18 / 2$ & 380 & 1.7 & 1.5 & 5.2 & 29.0 & 0.0 & 0.0 & 0.9 & 3.7 & 14.2 & 0.0 & 0.0 & 15.7 & 0.0 & 25.7 & 2.5 \\
\hline $157 / 1$ & $19 / 1$ & 390 & 0.4 & 4.3 & 0.8 & 2.4 & 2.6 & 9.1 & 17.2 & 21.6 & 33.6 & 0.0 & 0.0 & 2.8 & 0.0 & 4.1 & 1.1 \\
\hline $157 / 1$ & $19 / 2$ & 169 & 0.0 & 5.0 & 0.8 & 71.4 & 0.0 & 0.0 & 0.0 & 6.8 & 16.0 & 0.0 & 0.0 & 0.0 & 0.0 & 0.0 & 0.0 \\
\hline $157 / 1$ & $19 / 3$ & 21 & 0.0 & 5.9 & 0.0 & 0.0 & 0.0 & 0.0 & 12.7 & 21.4 & 34.1 & 0.0 & 0.0 & 0.0 & 0.0 & 25.9 & 0.0 \\
\hline $157 / 1$ & $20 / 1$ & 390 & 0.0 & 6.9 & 0.0 & 1.5 & 1.2 & 1.8 & 12.6 & 44.3 & 25.0 & 0.0 & 0.8 & 0.2 & 0.2 & 5.4 & 0.3 \\
\hline $157 / 1$ & $21 / 1$ & 210 & 6.1 & 0.0 & 0.0 & 9.3 & 0.0 & 0.9 & 6.2 & 23.4 & 51.3 & 0.0 & 0.0 & 2.8 & 0.0 & 0.0 & 0.0 \\
\hline $157 / 1$ & $21 / 2$ & 31 & 0.0 & 0.0 & 0.0 & 0.0 & 0.0 & 0.0 & 27.2 & 45.7 & 19.0 & 0.0 & 0.0 & 0.0 & 0.0 & 8.2 & 0.0 \\
\hline 155 & 1 & 2400 & 0.0 & 0.0 & 0.0 & 0.0 & 0.0 & 0.0 & 0.0 & 0.0 & 0.0 & 0.0 & 0.0 & 0.0 & 0.0 & 0.0 & 100.0 \\
\hline $155 / 1$ & 1 & 1050 & 0.0 & 0.0 & 0.0 & 0.0 & 0.0 & 0.0 & 0.0 & 0.0 & 0.0 & 0.0 & 0.0 & 0.0 & 0.0 & 0.0 & 100.0 \\
\hline 157 & 1 & 188 & 33.0 & 0.0 & 10.0 & 41.0 & 0.0 & 0.0 & 0.0 & 0.0 & 0.0 & 0.0 & 0.0 & 0.0 & 0.0 & 0.0 & 15.9 \\
\hline $157 / 1$ & 1 & 380 & 0.0 & 0.0 & 6.6 & 0.0 & 9.7 & 0.0 & 56.6 & 0.0 & 0.0 & 0.0 & 0.0 & 0.0 & 0.0 & 0.0 & 27.2 \\
\hline $155 / 1$ & 2 & 1050 & 0.0 & 0.0 & 0.0 & 0.0 & 0.0 & 0.0 & 0.0 & 0.0 & 0.0 & 0.0 & 0.0 & 0.0 & 0.0 & 0.0 & 100.0 \\
\hline $155 / 1$ & 3 & 300 & 0.7 & 0.0 & 0.0 & 1.3 & 3.1 & 0.0 & 27.8 & 5.0 & 61.6 & 0.0 & 0.0 & 0.4 & 0.0 & 0.0 & 0.0 \\
\hline 157 & 2 & 480 & 0.0 & 0.0 & 0.0 & 0.0 & 0.0 & 0.0 & 0.0 & 0.0 & 0.0 & 0.0 & 0.0 & 0.0 & 0.0 & 0.0 & 100.0 \\
\hline 157 & 3 & 470 & 0.0 & 0.0 & 0.0 & 0.0 & 0.0 & 0.0 & 0.0 & 0.0 & 0.0 & 0.0 & 0.0 & 0.0 & 0.0 & 0.0 & 100.0 \\
\hline 157 & 4 & 609 & 42.3 & 0.1 & 1.1 & 23.9 & 0.0 & 0.0 & 0.0 & 0.3 & 0.1 & 0.0 & 0.2 & 0.0 & 0.5 & 0.0 & 31.6 \\
\hline 157 & 5 & 480 & 0.0 & 0.0 & 0.0 & 0.0 & 0.0 & 0.0 & 0.0 & 0.0 & 0.0 & 0.0 & 0.0 & 0.0 & 0.0 & 0.0 & 100.0 \\
\hline 157 & 6 & 470 & 0.0 & 0.0 & 0.0 & 0.0 & 0.0 & 0.0 & 0.0 & 0.0 & 0.0 & 0.0 & 0.0 & 0.0 & 0.0 & 0.0 & 100.0 \\
\hline 157 & 7 & 390 & 0.0 & 0.0 & 0.0 & 0.0 & 0.0 & 0.0 & 0.0 & 0.0 & 0.0 & 0.0 & 0.0 & 0.0 & 0.0 & 0.0 & 100.0 \\
\hline 157 & 8 & 390 & 0.0 & 0.0 & 0.0 & 0.0 & 0.0 & 0.0 & 0.0 & 0.0 & 0.0 & 0.0 & 0.0 & 0.0 & 0.0 & 0.0 & 100.0 \\
\hline 157 & 9 & 390 & 0.0 & 0.0 & 0.0 & 0.0 & 0.0 & 0.0 & 0.0 & 0.0 & 0.0 & 0.0 & 0.0 & 0.0 & 0.0 & 0.0 & 100.0 \\
\hline 157 & 10 & 390 & 0.0 & 0.0 & 0.0 & 0.0 & 0.0 & 0.0 & 0.0 & 0.0 & 0.0 & 0.0 & 0.0 & 0.0 & 0.0 & 0.0 & 100.0 \\
\hline 157 & 11 & 390 & 0.0 & 0.0 & 0.0 & 0.0 & 0.0 & 0.0 & 0.0 & 0.0 & 0.0 & 0.0 & 0.0 & 0.0 & 0.0 & 0.0 & 100.0 \\
\hline 157 & 12 & 390 & 0.0 & 0.0 & 0.0 & 0.0 & 0.0 & 0.0 & 0.0 & 0.0 & 0.0 & 0.0 & 0.0 & 0.0 & 0.0 & 0.0 & 100.0 \\
\hline 157 & 13 & 390 & 0.0 & 0.0 & 0.0 & 0.0 & 0.0 & 0.0 & 0.0 & 0.0 & 0.0 & 0.0 & 0.0 & 0.0 & 0.0 & 0.0 & 100.0 \\
\hline 157 & 14 & 390 & 0.0 & 0.0 & 0.0 & 0.0 & 0.0 & 0.0 & 0.0 & 0.0 & 0.0 & 0.0 & 0.0 & 0.0 & 0.0 & 0.0 & 100.0 \\
\hline 157 & 15 & 390 & 0.0 & 0.0 & 0.0 & 0.0 & 0.0 & 0.0 & 0.0 & 0.0 & 0.0 & 0.0 & 0.0 & 0.0 & 0.0 & 0.0 & 100.0 \\
\hline $157 / 1$ & 2 & 380 & 0.0 & 0.0 & 0.0 & 0.0 & 0.0 & 0.0 & 0.0 & 0.0 & 0.0 & 0.0 & 0.0 & 0.0 & 0.0 & 0.0 & 100.0 \\
\hline $157 / 1$ & 3 & 380 & 0.0 & 0.0 & 0.0 & 0.0 & 0.0 & 0.0 & 0.0 & 0.0 & 0.0 & 0.0 & 0.0 & 0.0 & 0.0 & 0.0 & 100.0 \\
\hline $157 / 1$ & 4 & 380 & 0.0 & 0.0 & 0.0 & 0.0 & 0.0 & 0.0 & 0.0 & 0.0 & 0.0 & 0.0 & 0.0 & 0.0 & 0.0 & 0.0 & 100.0 \\
\hline $157 / 1$ & 5 & 380 & 0.0 & 0.0 & 0.0 & 35.8 & 1.7 & 0.0 & 0.0 & 8.9 & 21.8 & 0.0 & 0.0 & 0.0 & 0.0 & 0.0 & 31.8 \\
\hline $157 / 1$ & 6 & 380 & 0.0 & 0.0 & 7.2 & 4.3 & 15.9 & 0.0 & 8.8 & 17.8 & 34.7 & 0.0 & 0.0 & 0.0 & 0.0 & 0.0 & 11.3 \\
\hline $157 / 1$ & 7 & 380 & 0.0 & 0.0 & 0.0 & 0.0 & 0.0 & 0.0 & 0.0 & 0.0 & 0.0 & 0.0 & 0.0 & 0.0 & 0.0 & 0.0 & 100.0 \\
\hline $157 / 1$ & 8 & 58 & 0.0 & 0.0 & 0.0 & 0.0 & 0.0 & 0.0 & 14.8 & 28.4 & 22.8 & 0.0 & 0.0 & 10.3 & 0.0 & 23.7 & 0.0 \\
\hline $157 / 1$ & 9 & 380 & 0.0 & 0.0 & 2.0 & 4.1 & 20.4 & 2.3 & 15.6 & 19.5 & 34.3 & 0.0 & 0.0 & 1.0 & 0.0 & 0.8 & 0.0 \\
\hline $157 / 1$ & 10 & 1160 & 0.0 & 0.0 & 0.0 & 0.0 & 15.6 & 0.0 & 7.9 & 1.7 & 13.7 & 0.0 & 0.0 & 0.0 & 0.0 & 0.0 & 61.1 \\
\hline $157 / 1$ & 11 & 1160 & 0.0 & 0.0 & 3.3 & 8.1 & 0.0 & 4.6 & 12.3 & 0.0 & 3.2 & 0.0 & 0.0 & 0.0 & 0.0 & 0.0 & 68.4 \\
\hline $157 / 1$ & 12 & 1160 & 0.0 & 0.0 & 0.0 & 0.0 & 7.9 & 6.7 & 14.6 & 17.2 & 53.6 & 0.0 & 0.0 & 0.0 & 0.0 & 0.0 & 0.0 \\
\hline $157 / 1$ & 13 & 1160 & 1.0 & 0.0 & 10.8 & 2.9 & 7.5 & 8.6 & 39.8 & 22.0 & 6.0 & 0.0 & 0.0 & 0.1 & 0.0 & 0.0 & 1.2 \\
\hline $157 / 1$ & 14 & 1160 & 4.1 & 0.3 & 0.5 & 3.1 & 14.6 & 0.7 & 26.7 & 33.4 & 10.6 & 0.0 & 0.4 & 0.0 & 0.2 & 0.6 & 5.0 \\
\hline $157 / 1$ & 15 & 1137 & 0.0 & 2.4 & 1.1 & 7.4 & 2.6 & 1.1 & 12.0 & 27.1 & 34.0 & 0.5 & 0.5 & 3.8 & 0.8 & 6.6 & 0.0 \\
\hline
\end{tabular}


mal law with the parameters as described above. The chart of the modelling logic is shown in Fig. 3.

The $M$ number of simulations for SRW of one container was determined according to the volume of the loaded SRW in the container (but at least 5 simulations for each container) according to such equation:

$$
M=5+\operatorname{INT}\left(V_{\mathrm{SRW}} \cdot 50\right),
$$

where $V_{\text {SRW }}$ is the volume of SRW in the container, $\mathrm{m}^{3}$, $\operatorname{INT}(x)$ is the rounding function.

All simulated values were recorded in the memory of the computer, grouped to the waste storage sections where SRW was downloaded. In such a way, SRW of all containers was modelled and required statistics of the radionuclide activity ratio mixture was obtained for each section of the storage.

\subsection{Model of the waste storage section}

SRW containers from different collection points were downloaded in the corresponding storage sections. Contribution of different distributions of nuclide vector ratios NVR1-15, according to the volume of the SWR coming from different collection points, is shown in Table 2 for all waste storage sections.
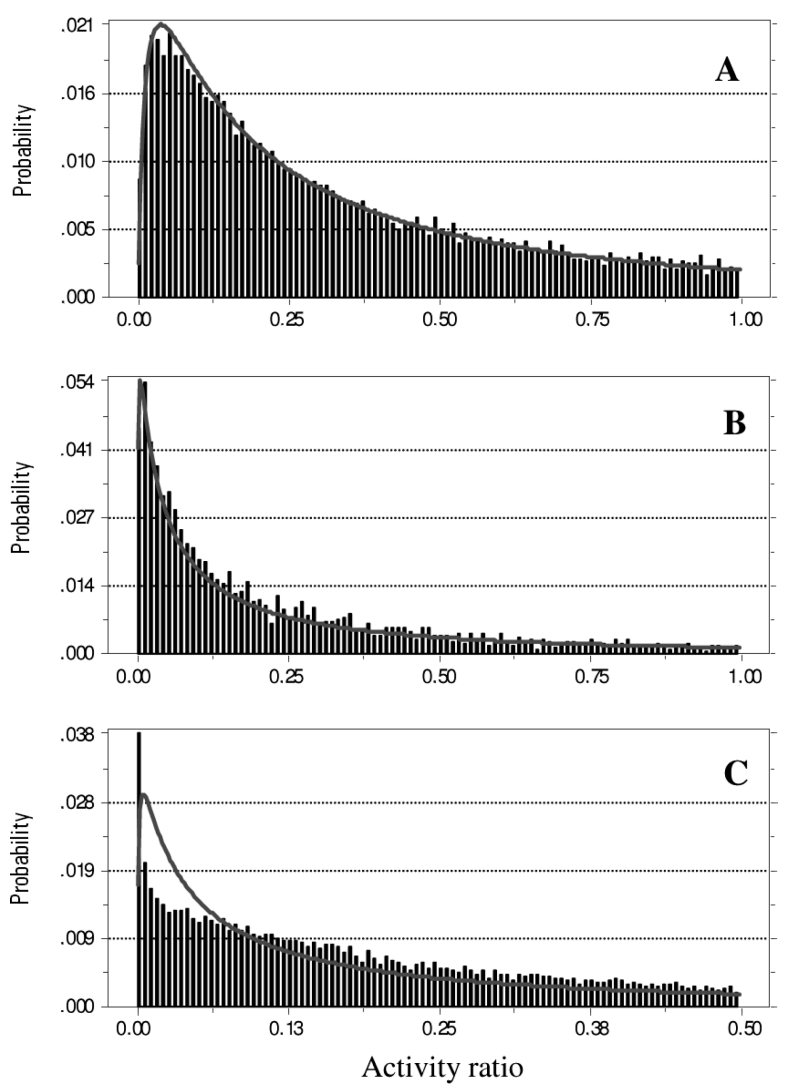

Fig. 4. Typical types of distributions of the modelled ${ }^{137} \mathrm{Cs} /{ }^{60} \mathrm{Co}$ activity ratios in the waste of the storage sections.
Table 3. Modelled mean and standard deviation values of ${ }^{137} \mathrm{Cs} /{ }^{60} \mathrm{Co}$ activity ratio and the estimated required number of samples $N$ to be taken from each storage section.

\begin{tabular}{|c|c|c|c|c|}
\hline $\begin{array}{c}\text { Facility } \\
\text { No }\end{array}$ & $\begin{array}{c}\text { Section } \\
\text { No }\end{array}$ & $\begin{array}{c}\text { Mean, } \\
\mu\end{array}$ & $\begin{array}{c}\text { Standard } \\
\text { deviation, } \sigma\end{array}$ & $N(100 \%)$ \\
\hline 155 & $1^{*}$ & 28.5 & 68.4 & 12 \\
\hline $155 / 1$ & 1 & 24.4 & 57.9 & 6 \\
\hline $157 / 1$ & 1 & 1.3 & 2.5 & 4 \\
\hline $155 / 1$ & 2 & 21.9 & 51.9 & 6 \\
\hline $155 / 1$ & 3 & 23.8 & 81.9 & 12 \\
\hline 157 & $2^{* *}$ & 18.6 & 107 & 14 \\
\hline 157 & 3 & 32.9 & 73.1 & 5 \\
\hline 157 & 5 & 15.0 & 35.9 & 6 \\
\hline 157 & 6 & 36.4 & 82.6 & 5 \\
\hline 157 & 7 & 12.6 & 27.8 & 5 \\
\hline 157 & 8 & 14.3 & 31.5 & 5 \\
\hline 157 & 9 & 32.8 & 75.5 & 5 \\
\hline 157 & 10 & 13.1 & 28.6 & 5 \\
\hline 157 & 11 & 29.0 & 67.8 & 5 \\
\hline 157 & 12 & 29.5 & 88.0 & 9 \\
\hline 157 & 13 & 28.0 & 73.7 & 7 \\
\hline 157 & 14 & 27.9 & 61.8 & 5 \\
\hline 157 & 15 & 31.4 & 73.7 & 6 \\
\hline $157 / 1$ & 2 & 10.9 & 25.1 & 5 \\
\hline $157 / 1$ & 3 & 15.5 & 38.0 & 6 \\
\hline $157 / 1$ & 4 & 13.4 & 30.1 & 5 \\
\hline $157 / 1$ & 5 & 18.8 & 50.7 & 7 \\
\hline $157 / 1$ & 6 & 11.3 & 41.3 & 13 \\
\hline $157 / 1$ & 7 & 7.3 & 16.3 & 5 \\
\hline $157 / 1$ & $8^{* *}$ & 1.4 & 14.1 & 14 \\
\hline $157 / 1$ & 9 & 10.9 & 48.1 & 19 \\
\hline $157 / 1$ & 10 & 7.3 & 29.1 & 16 \\
\hline $157 / 1$ & 11 & 2.8 & 6.4 & 5 \\
\hline $157 / 1$ & 12 & 31.0 & 102 & 11 \\
\hline $157 / 1$ & 13 & 18.1 & 61.6 & 12 \\
\hline $157 / 1$ & $14^{* *}$ & 12.4 & 129 & 14 \\
\hline $157 / 1$ & $15^{* *}$ & 4.8 & 106.6 & 14 \\
\hline $157 / 1$ & $16^{* *}$ & 101 & 731 & 14 \\
\hline $157 / 1$ & $17^{* *}$ & 2.5 & 25.3 & 14 \\
\hline $157 / 1$ & $18 / 1^{* *}$ & 1.6 & 13.6 & 14 \\
\hline $157 / 1$ & $18 / 2^{* *}$ & 5.0 & 36.1 & 14 \\
\hline $157 / 1$ & $19 / 1^{* *}$ & 1.0 & 8.3 & 14 \\
\hline $157 / 1$ & $19 / 2$ & 0.3 & 1.3 & 19 \\
\hline $157 / 1$ & $19 / 3^{* *}$ & 0.7 & 4.7 & 14 \\
\hline $157 / 1$ & $20 / 1^{* *}$ & 0.6 & 4.6 & 14 \\
\hline $157 / 1$ & $21 / 1^{* *}$ & 1.2 & 11.3 & 14 \\
\hline $157 / 1$ & $21 / 2^{* *}$ & 1.5 & 10.8 & 14 \\
\hline
\end{tabular}

* Amount of samples needed was doubled taking into account a large volume of facility No 155, section 1 .

** Doubled average amount of samples was assigned.

Evolution in time of the radionuclide activity ratio due to radioactive decay was also taken into account:

$$
\operatorname{NVR}(\Delta t)=\operatorname{NVR}\left(t_{0}\right) \exp \left[\left(\lambda_{60} \mathrm{Co}-\lambda_{137} \mathrm{Cs}\right) \Delta t\right],
$$

where $\Delta t$ is the time difference between the moment of SRW download to the section and the nuclide vector 
determination date, $\lambda_{60} \mathrm{Co}$ and $\lambda_{137} \mathrm{Cs}$ are ${ }^{60} \mathrm{Co}$ and ${ }^{137} \mathrm{Cs}$ radioactive decay constants, correspondingly.

\section{Results and discussion}

According to the above described methodology modelling of expected ${ }^{137} \mathrm{Cs}$ to ${ }^{60} \mathrm{Co}$ activity ratios was done for each waste storage section. Three typical determined types of distributions of the modelled ${ }^{137} \mathrm{Cs} /{ }^{60} \mathrm{Co}$ activity ratios in the waste of the storage sections are shown in Fig. 4.

The $\mathbf{A}$ type of the ratio distribution within the waste storage compartment is of the obvious lognormal type. Type $\mathbf{B}$ is of the similar distribution, but it has a significantly smaller geometric mean as compared to type A. Whereas, type $\mathbf{C}$ distribution reflects a mixture of two lognormal distributions with very different means (sharp peak in the range of small values and long "tail" in the range of large values). Nevertheless, Eq. (5) of the required number of samples is valid for all types of the obtained distributions, because the central limit theorem does not require having some specific type of distribution.

The calculated mean and standard deviation values of ${ }^{137} \mathrm{Cs} /{ }^{60} \mathrm{Co}$ activity ratio for each storage section are presented in Table 3. By using the obtained mean and standard deviation values of the ratios, a necessary amount of samples needed to be taken from the section of radioactive waste storage facilities has been assessed according to Eq. (5) (see Table 3 and Fig. 5). The obtained required average amount of samples needed was 7. For some cases (No 157, sections 1 and 4; No 157/1, sections $21 / 3$ and 18/3) the analysis of initial data has given no satisfactory answer due to missing information about activity measurements, therefore the amount of required samples has to be assessed separately by different methods and it is omitted. The amount of samples needed for the nuclide composition determination is doubled taking into account a large volume of facility No 155 , section 1 . For the other problematic storage sections, the double average number of required samples was assigned. Generally, the initial analysis demonstrates that the radioactive waste activity ratio variation in all sections is relatively similar, therefore the amount of samples differs about two times from the average (with the exception of facility No 157/1, sections 9, 10, 19/2, and sections with lacking information). This can be explained by stable operation of the INPP without any significant radiological incidents or accidents.

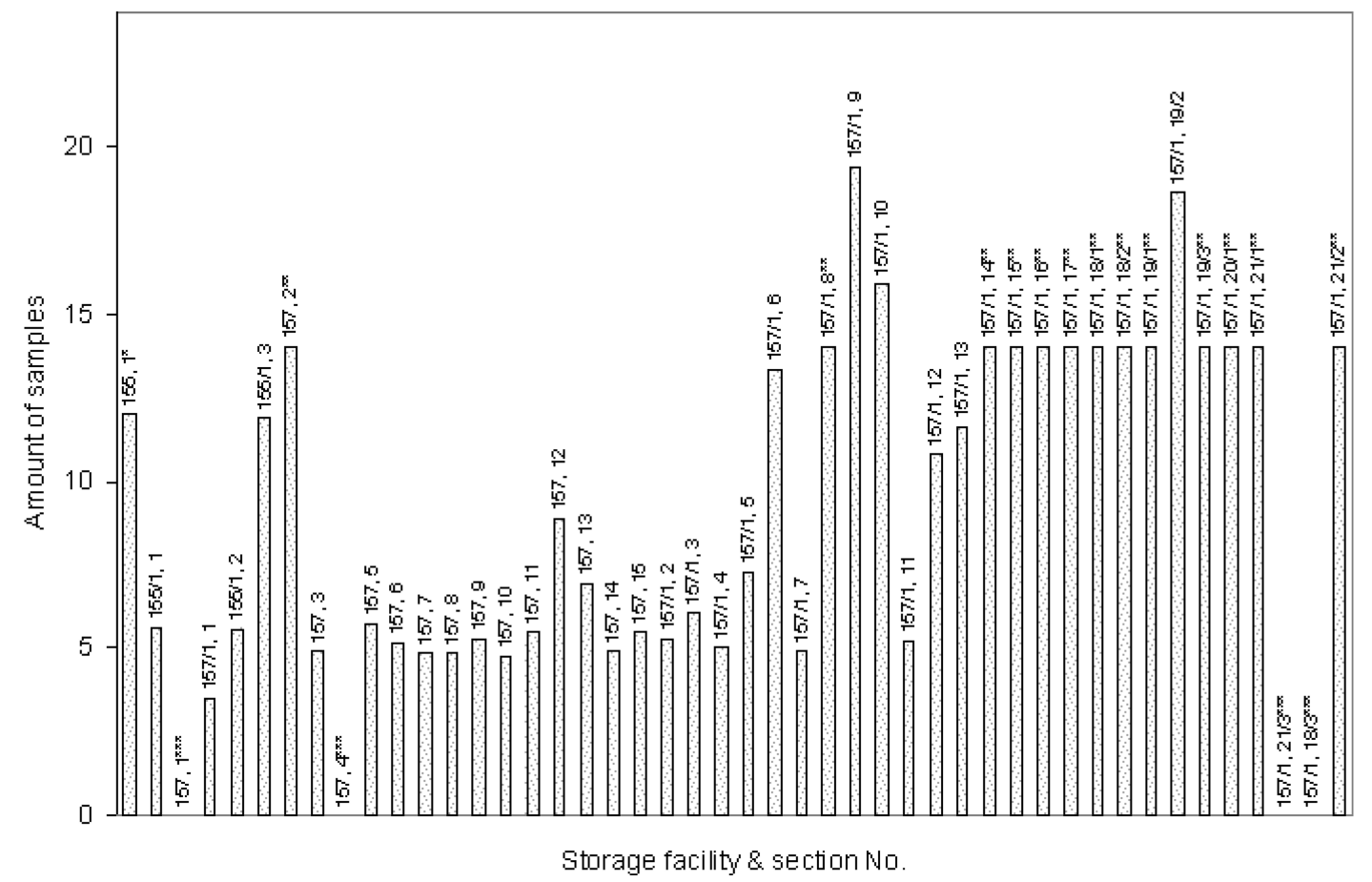

Fig. 5. Estimated amounts of samples needed to be taken from the section of radioactive waste storage facilities. ${ }^{*}-$ Amount of samples needed is doubled taking into account a large volume of facility No 155 , section $1 .^{* *}$ - Doubled average amount of samples was assigned. *** - Amount of samples needed is not known. 


\section{Conclusions}

A nuclide vector method is an optimal means for the characterization of the accumulated solid radioactive waste radionuclide composition at the INPP. Experimental measurement data of radionuclide activity are required to establish the correlations between difficult-to-measure and "key" radionuclides. Using computer modelling of the radioactive waste streams and Monte Carlo simulations of the most representative ${ }^{137} \mathrm{Cs} /{ }^{60} \mathrm{Co}$ activity ratio dispersions in the waste of storage sections are the best methods to evaluate the required optimal number of samples, needed to be taken from each storage section, and to evaluate scaling factors of the nuclide vector. Such modelling was done for the streams of waste at the INPP, based on the historical data about the SRW management at INPP and measurements of the nuclide composition of the main sources of contamination (spectrometric measurements of waste at the main waste collection points). The results of modelling have shown that the most typical type of the ${ }^{137} \mathrm{Cs} /{ }^{60} \mathrm{Co}$ scaling factor distribution is lognormal. The evaluated optimal average number of required samples from the SRW storage sections was 7, whereas the number of required samples varied from 4 (storage facility No $157 / 1$, section 1 ) to 19 (storage facility No 157/1, sections 9 and 19/2). The developed method of the waste characterization was practically applied and proved to be suitable for the characterization of the solid radioactive waste at the INPP.

\section{References}

[1] The Republic of Lithuania Law on Radioactive Waste Management No. VIII-1190, State News, 13 October 2005, No 122-4361, http://www3.lrs.lt/pls/inter2/ dokpaieska.showdoc_1?p_id=81441 [in Lithuanian].

[2] Regulation on the Pre-Disposal Management of Radioactive Waste at the Nuclear Power Plant, State News, 3 August 2001, No. 67-2467, http://www3.lrs. 1t/pls/inter3/dokpaieska.showdoc_1?p_id=146934 [in Lithuanian].

[3] Regulation on the Disposal of Low and Intermediate Activity Short-lived Radioactive Waste, State News, 8
November 2002, No. 106-4797, http://www3.lrs.lt/pls/ inter2/dokpaieska.showdoc_1?p_id=192802 [in Lithuanian].

[4] G. Klevinskas, L. Juodis, R. Plukienè, A. Plukis, and V. Remeikis, Analysis of iodine release from the defective fuel elements of the RBMK-1500 reactor, Lithuanian J. Phys. 47(2), 211-219 (2007).

[5] G. Klevinskas, L. Juodis, A. Plukis, R. Plukiene, and V. Remeikis, Determination of ${ }^{129}$ I activity in the RBMK-1500 main circulation circuit, Nucl. Eng. Des. 238, 1518-1524 (2008).

[6] W. Müller, Activity determination and declaration, in: Determination and Declaration of Nuclide Specific Activity Inventories in Radioactive Wastes, International workshop, Cologne, Germany, 2001, pp. 1-10.

[7] D. Lukauskas, R. Plukienè, A. Plukis, A. Gudelis, G. Duškesas, L. Juodis, R. Druteikienè, G. Lujanienè, B. Lukšiené, and V. Remeikis, Method to determine the nuclide inventory of low-activity waste of the RBMK-1500 reactor, Lithuanian J. Phys. 46(4), 497503 (2006).

[8] V. Remeikis, A. Plukis, L. Juodis, A. Gudelis, D. Lukauskas, R. Druteikienè, G. Lujanienè, B. Lukšienè, R. Plukienè, and G. Duškesas, Study of the nuclide inventory of operational radioactive waste for the RBMK-1500 reactor, Nucl. Eng. Des. 239, 813-818 (2009).

[9] Final Decommissioning Plan, Ignalina Nuclear Power Plant Decommissioning Project Management Unit, Issue 06 (INPP, Visaginas, 2004).

[10] J. Kruopis, Mathematical Statistics, 2nd ed. (Science and Encyclopaedia Publishers, Vilnius, 1993) [in Lithuanian].

[11] Examination of the nuclide composition and development of the method for the evaluation of the solid radioactive operational waste activity at Ignalina NPP. Program of the solid radioactive waste sampling from the canned sections of storage facilities, Document No: 07-00172-15.02 (Company "Specialus montažasNTP", Visaginas, 2008) [in Russian].

[12] Examination of the nuclide composition and development of the method for the evaluation of the solid radioactive operational waste activity at Ignalina NPP. Report on measurements of nuclide specific activity (gamma, beta, alpha) in samples, Document No: 0700172-17.02 (Company "Specialus montažas-NTP", Visaginas, 2009) [in Russian]. 


\title{
OPTIMALAUS BANDINIŲ KIEKIO NUSTATYMO PRINCIPAI CHARAKTERIZUOJANT IGNALINOS AE KIETĄSIAS RADIOAKTYVIĄSIAS ATLIEKAS
}

\author{
E. Maceika, V. Remeikis, L. Juodis, A. Gudelis, A. Plukis, R. Plukienė, G. Duškesas, D. Baltrūnas
}

Fizikos institutas, Vilnius, Lietuva

\begin{abstract}
Santrauka
Per Ignalinos atominès elektrinès (IAE) eksploatacijos laikotarpi (25 metus) susidare apie 7500 tonu kietuju radioaktyviųju atlieku (KRA), kurios yra laikinai saugomos keturiu saugyklų (Nr. $155,155 / 1,157,157 / 1) 45$ skyriuose IAE teritorijoje. Siekiant saugiai ir efektyviai nutraukti IAE eksploatacija, būtina žinoti šiose saugyklose saugomų atliekų radionuklidinę sudètị. Suděčiai nustatyti naudotas nuklidinio vektoriaus (NV) metodas. Norint ịvertinti nuklidinio vektoriaus proporcingumo koeficientu skaitines vertes, reikejo tinkamai suplanuoti kietujjų radioaktyviujju atliekų bandiniu paèmimą. Optimalus bandinių, kuriuos reikia paimti iš kiekvieno saugyklos skyriaus, skaičius $N$ buvo įvertintas remiantis gerai žinomu sąryšiu tarp vidurkio paklaidos $\Delta$ ir proporcingumo koefici-
\end{abstract}

ento dispersijos $\sigma: \Delta=\sigma / \sqrt{N}$. ${ }^{137} \mathrm{Cs}$ ir ${ }^{60}$ Co radionuklidu savituju aktyvumu santykis (proporcingumo koeficientas) buvo pasirinktas kaip informatyviausias, atspindintis NV dispersiją. Pasinaudojant sudarytu KRA srautų Ignalinos AE modeliu, Monte Karlo metodu modeliuota ${ }^{137} \mathrm{Cs}$ ir ${ }^{60} \mathrm{Co}$ aktyvumų santykio dispersija saugyklos skyriuose, remiantis prieinamais IAE saugomais duomenimis apie atliekų tvarkymą ir naujais radionuklidų aktyvumų matavimais pagrindiniuose IAE kietujų radioaktyviųju atliekų kaupimo punktuose. Nustatyta, kad vidutinis optimalus bandinių, kuriuos reikia paimti ir išmatuoti iš saugyklų skyrių, kiekis yra 7. Tačiau kai kuriems saugyklų skyriams reikiamas bandinių skaičius kito nuo 4 (saugyklos Nr. 157/1, 1 skyriui) iki 19 (saugyklos Nr. 157/1, 9 ir 19/2 skyriams). 